\title{
95 to 99 Percent of the Time
}

National Cancer Institute

\section{Source}

National Cancer Institute. 95 to 99 Percent of the Time. NCI Thesaurus. Code C157470.

An indication that an individual did something, or something occurred, between 95 and 99 percent of the time. 